\title{
An Adaptive Role of TNF $\alpha$ in the Regulation of Striatal Synapses
}

\author{
Gil M. Lewitus, ${ }^{1}$ Horia Pribiag, ${ }^{1}$ Rachna Duseja, ${ }^{1}$ Michel St-Hilaire, ${ }^{2}$ and David Stellwagen ${ }^{1}$ \\ ${ }^{1}$ Department of Neurology and Neurosurgery, Centre for Research in Neuroscience, The Research Institute of the McGill University Health Center, \\ Montreal, Quebec H3G 1A4, Canada, and 2McGill Psychiatry Program, Douglas Hospital Research Center, McGill University, Verdun, Quebec H3A 0G4, \\ Canada
}

Elevation of inflammatory cytokines in the striatum precedes symptoms in a number of motor dysfunctions, but it is unclear whether this is part of the disease process or an adaptive response to the pathology. In pyramidal cells, TNF $\alpha$ drives the insertion of AMPA-type glutamate receptors into synapses, and contributes to the homeostatic regulation of circuit activity in the developing neocortex. Here we demonstrate that in the mouse dorsolateral striatum, TNF $\alpha$ drives the internalization of AMPARs and reduces corticostriatal synaptic strength, dephosphorylates DARPP-32 and GluA1, and results in a preferential removal of $\mathrm{Ca}^{2+}$-permeable AMPARs. Striatal TNF $\alpha$ signaling appears to be adaptive in nature, as TNF $\alpha$ is upregulated in response to the prolonged blockade of D2 dopamine receptors and is necessary to reduce the expression of extrapyramidal symptoms induced by chronic haloperidol treatment. These data indicate that $\mathrm{TNF} \alpha$ is a regulator of glutamatergic synaptic strength in the adult striatum in a manner distinct from its regulation of synapses on pyramidal cells and mediates an adaptive response during pathological conditions.

\section{Introduction}

The striatum, which serves as the information processing hub of the basal ganglia, integrates sensorimotor, cognitive, and motivation-related information. The GABAergic medium spiny neurons (MSNs) comprise $>90 \%$ of neurons in the striatum and constitute its sole output, thus representing a critical node for information coding in the basal ganglia (Murer et al., 2002). MSNs integrate dopaminergic afferents from the midbrain and glutamatergic input from cortex and thalamus, and alterations in glutamatergic function are observed early in neurodegenerative diseases associated with movement disorders, such as Parkinson's disease (PD) and Huntington's disease (HD), as well as in several psychiatric disorders, such as drug addiction and schizophrenia (Kreitzer and Malenka, 2008). During many of these diseases, neuro-inflammatory processes are considered one of the key elements in the pathophysiology, especially the proinflammatory cytokine TNF $\alpha$ (McCoy and Tansey, 2008). TNF $\alpha$ is elevated in patients and in animal models of these diseases, even

Received Aug. 13, 2013; revised March 13, 2014; accepted March 19, 2014.

Author contributions: G.M.L., M.S.-H., and D.S. designed research; G.M.L., H.P., and R.D. performed research; G.M.L. and H.P. analyzed data; G.M.L. and D.S. wrote the paper.

This work was supported by Canadian Institutes of Health Research Grant 89904, Natural Sciences and Engineering Research Council, and the National Alliance for Research on Schizophrenia and Depression Young Investigator Award to D.S., the Ronald Peter Griggs Memorial Postdoctoral Fellowship in ALS Research to G.M.L., Fonds de la Recherche en Santé du Québec doctoral training award to H.P., and an award from the McGill University Psychiatry program to M.S.-H. We thank Joseph Lee for technical assistance and Dr. David E. Szymkowski (Biotherapeutics Xencor, Inc) for providing us with XENP1595 (DN-TNF).

The authors declare no competing financial interests.

Correspondence should be addressed to Dr. David Stellwagen, Centre for Research in Neuroscience, The Research Institute of the McGill University Health Centre, Montreal General Hospital L7-217, 1650 Cedar Avenue, Montréal, Québec H3G 1A4, Canada. E-mail: david.stellwagen@mcgill.ca.

DOI:10.1523/JNEUROSCI.3481-13.2014

Copyright $\odot 2014$ the authors $\quad 0270-6474 / 14 / 346146-10 \$ 15.00 / 0$ before the clinical manifestation of the disease (Khandelwal et al., 2011).

There is increasing evidence that $\mathrm{TNF} \alpha$ has a neuroregulatory function in addition to its role in the inflammatory response and in cell survival. In the hippocampus (Stellwagen et al., 2005) and cortex (He et al., 2012), TNF $\alpha$ regulates neurotransmitter receptor trafficking, with exogenous application of TNF $\alpha$ leading to a dramatic and rapid exocytosis of AMPA receptors (AMPARs) on excitatory pyramidal neurons. Furthermore, continual release of TNF $\alpha$ may be necessary for maintaining the surface expression of AMPARs, as blockade of TNF $\alpha$ signaling leads to decreased strength at hippocampal synapses (Beattie et al., 2002). Importantly, TNF $\alpha$ released from glia is a key mediator of homeostatic synaptic plasticity. In this context, TNF $\alpha$ modifies both AMPAR and $\mathrm{GABA}_{\mathrm{A}} \mathrm{R}$ trafficking in pyramidal cells to normalize activity levels in a neuronal circuit in response to chronic activity manipulations (Stellwagen and Malenka, 2006). Furthermore, TNF $\alpha$ mediates homeostatic plasticity in vivo, as it is necessary for the increase in visual cortical response after chronic monocular deprivation during a developmental critical period (Kaneko et al., 2008; Ranson et al., 2012).

Here we investigate the contribution of TNF $\alpha$ to AMPAR trafficking in MSNs from the dorsal striatum and its relevance to motor disorders. At striatal glutamatergic synapses, TNF $\alpha$ application results in a decreased AMPA/NMDA ratio, which is accompanied by decreased AMPAR rectification and spontaneous EPSC (sEPSC) amplitude. Given recent evidence suggesting that the development and expression of drug-induced movement disorders are linked to aberrant striatal plasticity (Breakefield et al., 2008), we took advantage of a haloperidol-induced extrapyramidal syndrome model to investigate the role of $\mathrm{TNF} \alpha$ in striatal function in vivo. We show here that, in the absence of TNF $\alpha$ 
signaling, both the physiological and behavioral consequences of chronic haloperidol treatment are augmented relative to controls. Critically, this deficit can be rescued by restoring TNF $\alpha$ signaling. This study thus identifies TNF $\alpha$ as a key regulator of striatal synaptic function.

\section{Materials and Methods}

Animals. TNF $\alpha^{-1-}$ mice were obtained from The Jackson Laboratory (RRID:IMSR_JAX:005540), bred homozygously, and compared with wild-type mice of matched genetic background (C57BL/6J), also bred in house. Experiments only used male mice at 8-11 weeks of age. Animal procedures were performed in accordance with the guidelines of the Canadian Council for Animal Care and the Montreal General Hospital Facility Animal Care Committee.

Drugs. Mouse TNF $\alpha$ was obtained from Kamiya Biomedical. Haloperidol decanoate (Haloperidol-LA) (Sandoz) was administered at a concentration of $50 \mathrm{mg} / \mathrm{kg}$, intramuscularly. This decanoate formulation is known to result in constant plasma levels in the $2.5 \mathrm{mg} / \mathrm{kg} / \mathrm{d}$ range (Ethier et al., 2004). Haloperidol (Sandoz) was injected intraperitoneally at a concentration of 0.1 or $0.5 \mathrm{mg} / \mathrm{kg}$. XENP1595 (DN-TNF; Biotherapeutics Xencor) was injected subcutaneously at $30 \mathrm{mg} / \mathrm{kg}, 2 \mathrm{~d}$ before recording. Striatal slices were incubated with $10 \mu \mathrm{g} / \mathrm{ml}$ DN-TNF in the recording chamber. For behavioral experiments, XENP1595 was maintained at $15 \mathrm{mg} / \mathrm{kg}$, injected SC every $2 \mathrm{~d}$. IEM-1460 (Tocris Bioscience) was injected intraperitoneally at $3 \mathrm{mg} / \mathrm{kg}, 20 \mathrm{~min}$ before assessment.

Electrophysiology. The $240-\mu \mathrm{m}$-thick coronal slices containing dorsal striatum were prepared from $T N F \alpha^{-1-}$ or C57BL/6J mice. Transverse hippocampal slices $(300 \mu \mathrm{m})$ were prepared from C57BL/6J mice. After a $1 \mathrm{~h}$ recovery period, slices were placed in a submersion-type recording chamber and perfused $(1.5-2 \mathrm{ml} / \mathrm{min})$ at $30^{\circ} \mathrm{C}$ with a bicarbonatebuffered artificial CSF saturated with $95 \% \mathrm{O}_{2} / 5 \% \mathrm{CO}_{2}$ and containing the following (in mM): $119 \mathrm{NaCl}, 2.5 \mathrm{KCl}, 1 \mathrm{NaH}_{2} \mathrm{PO}_{4}, 1.3 \mathrm{MgCl}_{2}, 2.5$ $\mathrm{CaCl}_{2}, 26.2 \mathrm{NaHCO}_{3}, 11$ glucose, 0.05 picrotoxin. Whole-cell voltageclamp recordings were obtained under visual control using infrareddifferential interference contrast microscopy (Olympus, BX51WI). Whole-cell electrodes $(4-6 \mathrm{~m} \Omega$ ) were filled with internal solution containing the following (in mM): 120 Cs-gluconate, 10 HEPES, 10 EGTA, $15.5 \mathrm{CsCl}, 8 \mathrm{NaCl}, 2 \mathrm{MgATP}$, and $0.3 \mathrm{GTP}, \mathrm{pH}$ 7.3. All signals were acquired with an Axopatch 200B (Molecular Devices), filtered at $2 \mathrm{kHz}$ and digitized at $10 \mathrm{kHz}$, and recorded using Clampex 10.2 (Molecular Devices). Passive membrane properties of the cells were monitored throughout the experiment. The series resistance was $<25 \mathrm{M} \Omega$ and was not compensated. If the series resistance changed $>20 \%$ during the course of an experiment, the data were discarded.

Stimulus-evoked EPSCs were evoked using stainless-steel bipolar stimulating electrodes placed in the cortical areas close to the recording electrode or in the white matter between the cortex and the striatum to preferentially activate corticostriatal fibers. The slight paired pulse depression (0.95-0.98; see Fig. 1I) observed suggests some degree of contamination with thalamic and other glutamatergic inputs, but corticostriatal fibers are predominant. To calculate AMPA/NMDA ratios, we collected evoked synaptic responses at $-70 \mathrm{mV}$ to measure AMPARmediated EPSCs and at $+40 \mathrm{mV}$ to measure NMDAR-mediated EPSCs. The peak AMPA response was used to calculate the AMPAR component, and the amplitude of the NMDA component was measured $40 \mathrm{~ms}$ from the AMPAR peak response at $-70 \mathrm{mV}$. This offset method represents a relatively pure NMDA component. The rectification index (RI) was calculated as the ratio of EPSC amplitudes between -70 and $+40 \mathrm{mV}$. All RI experiments were performed in slices bathed in picrotoxin to block $\mathrm{GABA}_{\mathrm{A}}$ receptor-mediated responses and AP-5 $(50 \mu \mathrm{M})$ to block NMDA receptor-mediated responses.

To estimate the paired pulse ratio (PPR), 15 paired pulse synaptic stimulations with an interstimulus interval of $50 \mathrm{~ms}$ at a holding potential of $-70 \mathrm{mV}$ were delivered through the stimulating electrode with $10 \mathrm{~s}$ intervals. The traces were averaged, and PPR was expressed as percentage of the ratio of the second pulse to the first one in the series. The amplitude and frequency of sEPSCs were sampled over $2 \mathrm{~min}$, at a holding potential of $-70 \mathrm{mV}$. sEPSCs were analyzed off-line using the threshold detection option in Clampfit 10.2 (Molecular Devices). The threshold amplitude for the detection of an event was set at $5 \mathrm{pA}$.

Quantification of vacuous chewing movements (VCMs). To quantify the occurrence of oral movements, mice were placed individually in observation cages and the frequency of vacuous chewing movements was quantified. Vacuous chewing movements are operationally defined as single mouth openings in the vertical plane not directed toward physical material. If vacuous chewing movements occurred during a period of grooming, they were not taken into account. The animals were observed for 3 consecutive sessions of $3 \mathrm{~min}$ each, for a total observation period of $9 \mathrm{~min}$. Average VCM scores per $3 \mathrm{~min}$ were then calculated from these observations.

Catalepsy test. Catalepsy was measured as the length of time a mouse maintained an imposed abnormal posture. Mice were gently positioned with both front legs on a 2 -mm-diameter horizontal rod placed at a height of $3 \mathrm{~cm}$. The time elapsed, up to $60 \mathrm{~s}$, before the mouse returned both front paws to the ground was measured. Mice were observed at intervals of 15, 30, 60, and 90 min after intraperitoneal administration of haloperidol $(0.1 \mathrm{mg} / \mathrm{kg})$.

Surface biotinylation and Western blots. Surface biotinylation was performed essentially as described previously (Jones et al., 2011). Striatal slices were incubated with sulfo-NHS-SS-biotin in aCSF ( $1 \mathrm{mg} / \mathrm{ml})$ for 40 $\min$ at $4^{\circ} \mathrm{C}$. The biotin reaction was quenched using aCSF containing 100 mM glycine. Slices were lysed on ice with PBS/1\% Triton X-100/0.1\% SDS supplemented with protease inhibitors, sodium fluoride, PMSF, and sodium orthovanadate. An aliquot of lysate was kept for analysis of total protein levels. Biotinylated receptors were precipitated with Neutravidin beads for $1 \mathrm{~h}$ at $4^{\circ} \mathrm{C}$ on a rotating platform and eluted with $3 \times$ sample buffer. Samples were resolved using SDS-PAGE and transferred to PVDF membrane. Blots were incubated overnight at $4^{\circ} \mathrm{C}$ using the following antibodies: GluA1 (Millipore, catalog \#AB1504, RIID:AB_2113602), GluN1 (BD Biosciences, catalog \#556308, RIID:AB_396353), GluA1 phospho-S831 (EMD Millipore, catalog \#04-823, RIID:AB_1977218), GluA1 phospho-S845 (EMD Millipore, catalog \#04-1073, RIID: AB_1977219), DARPP-32 phospho-T34 (R\&D Systems, catalog \#AF2847, RIID:AB_2252832), total DARPP-32 (Abcam, catalog \#ab40801, RIID:AB_731843), D2 receptor (Abcam, catalog \#ab85367, RIID:AB_10674739), and GAPDH (Millipore, catalog \#MAB374, RIID: AB_2107445). After incubation with HRP-conjugated secondary antibody (Jackson ImmunoResearch Laboratories), blots were developed using ECL substrate (34096, Thermo Scientific). Band intensities were determined using ImageJ and normalized as follows: for surface GluA1, surface GluN1, and surface D2, surface values were normalized to their corresponding inputs and to biotinylated GAPDH (to normalize for differential permeabilization); $\mathrm{p}$-S831 and p-S845 were normalized to total GluA1; p-T34 DARPP-32 was normalized to total DARPP-32; and total DARPP-32 was normalized to GAPDH.

Statistical analysis. Statistical analyses were performed using JMP 8 (SAS Institute) and Prism 5 (GraphPad Software). All data are presented as mean \pm SEM. Data were tested for normality using the Shapiro-Wilk Test and then compared using the two-tailed Student's $t$ test; multiple comparisons were analyzed by one-way ANOVA for independent and/or repeated measures followed by post hoc Fisher's least significant difference. The Mann-Whitney test was used for Western blot analyses. The significance level was established at $p<0.05$.

\section{Results}

\section{TNF $\alpha$ regulates AMPA receptor content at} corticostriatal synapses

To investigate the effect of TNF $\alpha$ at synapses onto MSNs in the dorsolateral striatum, we incubated acutely prepared coronal slices from mice with $100 \mathrm{ng} / \mathrm{ml} \mathrm{TNF} \alpha$ for $1-2 \mathrm{~h}$ and then assayed the strength of the glutamatergic input by measuring the ratio of AMPAR- to NMDAR-mediated EPSCs. Based on stimulating electrode placement and paired pulse response (Ding et al., 2008), the input predominantly consists of corticostriatal fibers with some contamination of thalamic and other inputs. Incubation of striatal slices with TNF $\alpha$ significantly reduced the AMPA/ 
NMDA ratio compared with interleaved control slices from the same animal (Fig. $1 A, B)$. TNF $\alpha$ treatment did not significantly alter the decay kinetics of either the AMPA current (Cont: $\tau=3.35 \pm 0.09$; $n=16$; TNF $\alpha: 3.58 \pm 0.11 n=11 ; p=$ 0.16 ) or the NMDA current (Cont: $\tau=$ $30.94 \pm 1.47 ; n=16$; TNF $\alpha: 34.32 \pm 1.63$ $n=13 ; p=0.14)$. To verify that the reduction in AMPA/NMDA ratio observed in the MSNs in response to TNF $\alpha$ is distinct from the increase in AMPA/NMDA ratio in hippocampal pyramidal cells (Stellwagen and Malenka, 2006) and not the result of differences in experimental design (age of animal or dosage of TNF $\alpha$ ), we repeated the above experiment in adult hippocampal slices. As expected, incubation of adult hippocampal slices with 100 $\mathrm{ng} / \mathrm{ml} \mathrm{TNF} \alpha$ significantly enhanced the AMPA/NMDA ratio in CA1 pyramidal cells compared with control slices from the same animal (Fig. $1 A, B$ ). This indicates the response of MSNs to TNF $\alpha$ is fundamentally different from the response of hippocampal or cortical pyramidal cells.

To determine whether the change in AMPA/NMDA ratio in the MSNs was the result of a change in AMPAR content, we examined spontaneous EPSC (sEPSC) amplitude after $\mathrm{TNF} \alpha$ treatment. $\mathrm{TNF} \alpha$ significantly decreased sEPSC amplitude compared with untreated MSNs (Fig. $1 C-E$ ) but had no significant impact on spontaneous event frequencies (50.9 \pm 4.5 events $/ \mathrm{min} ; n=15$ for control; $56.9 \pm$ 3 events/min; $n=14$ for TNF $\alpha$ treatment; $p=0.29)$. sEPSCs, unlike miniature EPSCs (mEPSCs), could be contaminated by spontaneously occurring action potentials that would potentially activate multiple synapses and complicate interpretation. However, the cell bodies of the glutamatergic afferents are not located in the slice, making this unlikely; and sEPSCs in dorsostriatal slices have been shown to be action potential independent (Tang and Lovinger, 2000). Furthermore, we compared sEPSCs to mEPSCs by adding TTX during recording. TTX treatment did not reduce the frequency of sEPSCs $(67 \pm 9.6$ events/min preTTX; $79 \pm 9$ events/min after TTX; $p>0.40 ; n=4$ cells), suggesting that few, if any, action potentials are occurring. The sEPSC data suggest that TNF $\alpha$ treatment decreases AMPAR content but has no effect on release probability. To determine whether TNF $\alpha$ signaling has an effect on presynaptic function, we also examined PPR, which is inversely correlated with the probability of neurotransmitter release (Dobrunz and Stevens, 1997). There were no significant differences in PPR between the different groups $(0.94 \pm 0.03 ; n=$ 12 for control; $0.98 \pm 0.03 ; n=8$ for TNF $\alpha ; p=0.39$ ), suggesting that TNF $\alpha$ is not altering presynaptic properties at these synapses. On pyramidal cells, TNF $\alpha$ increases the synaptic content of $\mathrm{Ca}^{2+}$-permeable AMPARs (CP-AMPAR) (Ogoshi et al., 2005;
Stellwagen et al., 2005), which are characterized by an inwardrectifying current-voltage relationship (Bowie and Mayer, 1995; Kamboj et al., 1995). In MSNs, the corticostriatal synapse is thought to contain a small population of $\mathrm{Ca}^{2+}$-permeable AMPA receptors (Carter and Sabatini, 2004; but see Gittis et al., 2011). We observed a substantial amount of rectification at striatal synapses, indicting the presence of CP-AMPARs (Fig. $1 F$ ). Incubation of striatal slices with TNF $\alpha$ significantly decreased this rectification compared with untreated slices (Fig. $1 F, G$ ). To further evaluate the effects of TNF $\alpha$ on CP-AMPARs, we incubated slices treated with TNF $\alpha$ or control with IEM-1460, an inhibitor of CP-AMPARs, and measured the change in the EPSC. IEM-1460 significantly reduced EPSCs in control slices but did not affect TNF $\alpha$-treated slices (Fig. $1 H, I)$. Together, these results suggest that TNF $\alpha$ treatment results in preferential removal of CP-AMPARs on MSNs. 

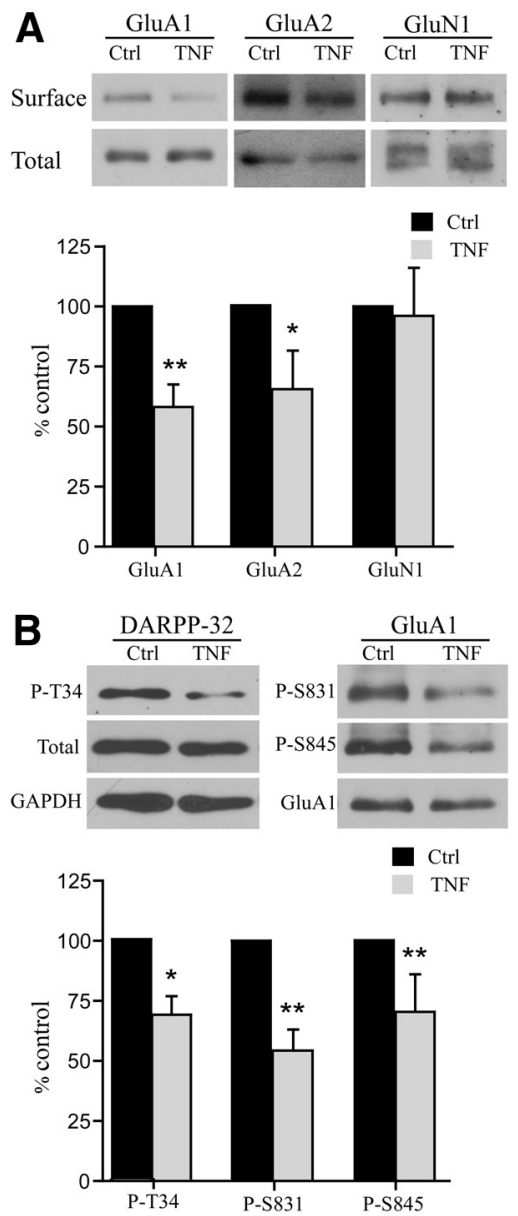

Figure 2. TNF $\alpha$ treatment significantly reduces surface AMPAR levels in the striatum. Striatal slices were treated with TNF $\alpha 100 \mathrm{ng} / \mathrm{ml}$ for $1 \mathrm{~h}$ and analyzed by surface biotinylation for (A) surface GluA1 ( $n=10$ mice), surface GluA2 ( $n=7$ mice) and surface GluN1 ( $n=8$ mice) and were compared with the total corresponding protein level. The protein loading for surface exceeds the loading for total in some cases. Only the decrease in AMPAR subunit surface expression was significant (GluA1: $p=0.002 ;$ GluA2: $p=0.02$; GluN1: $p=0.96$ ). $\boldsymbol{B}$, TNF $\alpha$ treatment significantly decreased the phosphorylation of DARPP-32 T34 ( $n=7$ mice), and both GluA1S831 ( $n=7$ mice) and GluA1-S845 ( $n=8$ mice) ( $\mathrm{p}-\mathrm{T} 34: p=0.02 ; \mathrm{p}-\mathrm{S} 831: p=0.0011$; $p$-S845: $p=0.001$ ), with no change in total protein expression of either DARPP-32 or GluA1 (GluA1: $p=0.96$; DARPP-32: $p=0.17$ ). Data are mean \pm SEM. ${ }^{*} p<0.05 .{ }^{* *} p<0.01$.

To directly assess whether there is a downregulation in the surface expression of AMPARs, we used surface biotinylation on striatal slices treated with $100 \mathrm{ng} / \mathrm{ml} \mathrm{TNF} \alpha$ for $1 \mathrm{~h}$ and compared this with untreated slices from the same animals. TNF $\alpha$ treatment markedly decreased the surface expression of GluA1 and, to a lesser extent, surface expression of GluA2, but had no effect on the requisite NMDAR subunit GluN1 (Fig. 2A). This is consistent with the electrophysiological data suggesting that the TNF $\alpha$ induced change in AMPA/NMDA ratio is the result of a change in AMPARs and not NMDARs. In MSNs, the surface expression of AMPARs is regulated by protein phosphatase 1 (PP1), which in turn is regulated by DARPP-32 (Yan et al., 1999). Dephosphorylation of DARPP-32 at T34 results in dissociation of DARPP-32 and PP1, activation of PP1, and AMPAR endocytosis (Yan et al., 1999). TNF $\alpha$ may act through this pathway, as we observed a decrease in DARPP-32 T34 phosphorylation in TNF $\alpha$-treated slices, compared with untreated slices from the same animal (Fig. $2 B$ ), without affecting the total protein level $(96.5 \pm 10.9 \%$ of control). Consistent with a decrease in AMPAR surface expression as well as the activation of PP1, we also observed a decrease in phosphorylation of both S845 and S831 on GluA1 in the total protein fraction of $\mathrm{TNF} \alpha$-treated slices (Fig. $2 B$ ), without a change in total GluA1 (105.6 $\pm 10.8 \%$ of control). Together, these data suggest that, through the regulation of DARPP-32 activity, TNF $\alpha$ drives the endocytosis of AMPARs in MSNs, as opposed to the exocytosis of AMPARs observed with pyramidal cells.

\section{TNF $\alpha$ regulates the development of dyskinetic symptoms} induced by haloperidol

TNF $\alpha$ is known to homeostatically regulate circuit function in the hippocampus and the visual cortex (Stellwagen and Malenka, 2006; Kaneko et al., 2008). Although the effect of TNF $\alpha$ on AMPAR trafficking is reversed in MSNs compared with pyramidal cells, we wanted to test whether TNF $\alpha$ was still acting to normalize circuit function in the striatum.

To test the role of TNF $\alpha$ in regulating striatal-dependent behavior, we first examined the effect of inhibiting TNF $\alpha$ signaling at synapses onto MSNs. We used both genetic and pharmacological methods to block TNF $\alpha$ signaling. We first examined the effect of genetically deleting TNF $\alpha$ by using knock-out mice ( $\mathrm{TNF}^{-/-}$mice). Basal AMPA/NMDA current amplitudes were significantly higher in the $T N F \alpha^{-/-}$mice compared with WT mice (Fig. $3 A, B$ ), suggesting ongoing TNF $\alpha$ signaling in the striatum. However, to exclude compensatory mechanisms resulting from the absence of $\mathrm{TNF} \alpha$ during development creating this change, we pharmacologically blocked the soluble form of TNF $\alpha$ in adult mice using XENP1595 (an engineered dominantnegative variant of TNF $\alpha$ [DN-TNF] that rapidly binds with soluble $\mathrm{TNF} \alpha$ to give heterotrimers that neither bind to nor stimulate signaling through TNF receptors) (Steed et al., 2003). WT mice were administered DN-TNF (30 mg/kg, i.p.) $2 \mathrm{~d}$ before striatal slice preparation, and slices were subsequently incubated in $10 \mu \mathrm{g} / \mathrm{ml} \mathrm{DN-TNF}$ to block any TNF $\alpha$ released because of slicing. Blocking TNF $\alpha$ signaling increased AMPA/NMDA ratios (Fig. $3 A, B$ ) to a similar degree observed in the $T N F \alpha^{-1-}$ mice. Furthermore, blocking TNF $\alpha$ signaling for $48 \mathrm{~h}$ in vivo significantly increased the sEPSC amplitude compared with control (Fig. 3C-E) but did not significantly affect spontaneous event frequencies ( $89.1 \pm 14$ events/min; $n=14$ for control; $63.8 \pm 10$ events/min; $n=14$ for DN-TNF treatment; $p=0.16$ ). Consistent with the lack of change in sEPSC frequency, we did not observe any significant differences in PPR between the different groups $(0.94 \pm 0.03 ; n=12$ for control; $0.89 \pm 0.04 ; n=9$ for DN-TNF; $p=0.4)$. In addition, we also examined the rectification of the AMPA-mediated EPSC after DN-TNF treatment. Synapses from DN-TNF-treated slices showed increased rectification compared with untreated slices (Fig. $3 F, G$ ). Together, these results suggest that there is ongoing TNF $\alpha$ signaling in the striatum that downregulates surface AMPARs and limits synaptic strength at corticostriatal synapses.

Abnormalities in the corticostriatal pathway are associated with a number of movement disorders, such as drug-induced extrapyramidal symptoms (Centonze et al., 2004), PD (Watson et al., 2009), and HD (Milnerwood and Raymond, 2007), which are all associated with increased striatal TNF $\alpha$ levels (Bishnoi et al., 2008; Khandelwal et al., 2011; Smith et al., 2012). This raises the possibility that TNF-mediated plasticity is a compensatory response to the development of striatal dysfunctions. To investigate the role of TNF $\alpha$ in an experimental movement disorder, we used a mouse model of extrapyramidal disorder induced by subchronic blockade of striatal dopamine $\mathrm{D}_{2}$ receptors by antipsychotic drugs and characterized by involuntary movements, 
A
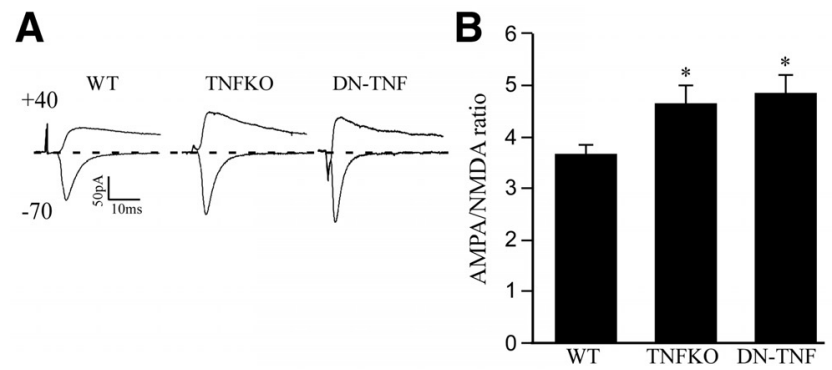

\section{C}
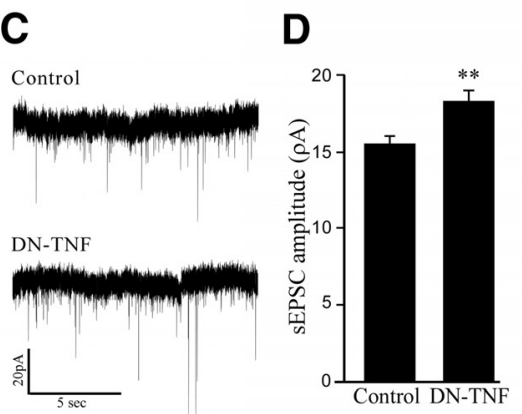

E

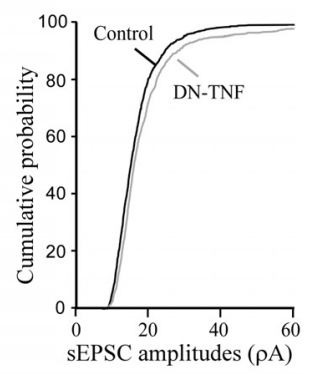

$\mathbf{F}$

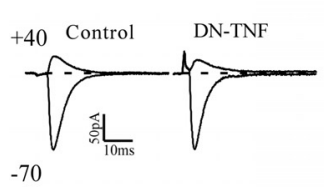

G

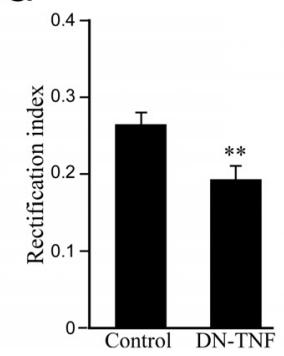

Figure 3. Blocking TNF $\alpha$ signaling increases AMPA receptor content at striatal synapses. $\boldsymbol{A}$, Representative traces from striatal medium spiny neurons with the cell held at $-70 \mathrm{mV}$ (bottom) and $+40 \mathrm{mV}$ (top) in slices from WT mice (left), TNF $\alpha^{-/-}$mice (TNFKO) (middle), and WT slices treated with a dominant-negative form of TNF $\alpha$ (DN-TNF) (right). B, Group data showing that, in TNF $\alpha^{-1-}$ mice and WT slices treated with DN-TNF, there is a significantly higher ratio of AMPA to NMDA current amplitudes. AMPA/NMDA ratios were calculated using the peak amplitude at $-70 \mathrm{mV}$ for AMPA and the amplitude at $+40 \mathrm{mV}$ taken $40 \mathrm{~ms}$ after the peak at $-70 \mathrm{mV}$. A one-way ANOVA demonstrated a significant effect of the treatment $(n=$ 15-17 per group; $\left.F_{(2,48)}=3.9, p<0.026\right)$. C, Representative recordings of SEPSC s from control slices and slices treated with DN-TNF. D, Mean sEPSC amplitude is significantly increased by DN-TNF treatment (18.2 $\pm 0.6 \mathrm{pA}$ vs $15.3 \pm 0.4 \mathrm{pA} ; n=14 ; p=0.001)$. $\boldsymbol{E}$, Cumulative distributions of sEPSC amplitudes. $\boldsymbol{F}$, Sample traces of isolated AMPAR EPSCs at +40 and -70 $\mathrm{mV}$. G, Group data demonstrating that synapses from DN-TNF-treated slices have increased rectification relative to untreated slices. The RI is expressed as EPSC amplitude $+40 \mathrm{mv} / \mathrm{EPSC}$ amplitude $_{-70 \mathrm{my^{ \prime }}}$ with a larger ratio indicating less rectification $(n=10-12) . p=0.005$. Data are mean \pm SEM. ${ }^{*} p<0.05 .{ }^{* *} p<0.01$.

particularly of the face and neck. In mice, subchronic haloperidol is associated with reduced dynorphin and substance $\mathrm{P}$, similar to that seen with an animal model of Parkinsonism and druginduced extrapyramidal symptoms (Egan et al., 1996) and manifests as purposeless mouth openings in the vertical plane, or VCMs. In this model, TNF $\alpha$ levels were shown to be elevated in the striatum after chronic administration of haloperidol (Bishnoi et al., 2008; Wang et al., 2012), accompanied with increased striatal AMPA binding (Schmitt et al., 2003).

To get higher and more stable VCMs, we generated the VCMs by a single injection of a high dose of the slow release formulation of the drug (Ethier et al., 2004), haloperidol decanoate $(50 \mathrm{mg} / \mathrm{kg}$, i.m., equivalent of $2.5 \mathrm{mg} / \mathrm{kg} / \mathrm{d}$ ) to WT mice and $T N F \alpha^{-1-}$ mice. Although both strains of mice developed VCMs, the VCMs scores were significantly higher in $T N F \alpha^{-/-}$mice compared with WT mice (Fig. 4A). Furthermore, a small group of mice were monitored for an extended period of time, and VCMs were still elevated after 10 weeks in the TNF $\alpha^{-/-}$mice as opposed to WT mice that returned to basal levels after 8 weeks. These results suggest that $\mathrm{TNF} \alpha$ is reducing the adverse effects of chronic administration of haloperidol. To exclude the possibility that $\mathrm{TNF} \alpha$ was simply modulating the response to haloperidol, we tested the acute response to haloperidol. As opposed to the chronic response to slow-release haloperidol, acute administration of fastacting haloperidol induces a rapid cataleptic state mainly because of the blockade of dopamine receptors in the nigrostriatal pathway (Sanberg, 1980). This profound cataleptic state can be measured by an increase in the latency to initiate voluntary movement, such as removing the forelimbs from an elevated bar (Sanberg et al., 1988). To verify that TNF $\alpha$ is not involved in the acute response to haloperidol, we injected WT and $T N F \alpha^{-1-}$ mice with fast-acting haloperidol $(0.1 \mathrm{mg} / \mathrm{kg}$ i.p. $)$ while monitoring cataleptic behavior in the elevated bar test, and found no significant differences between the two groups of mice (Fig. $4 B$; $n=9)$. In addition, no significant differences were observed with a higher dosage $(0.5 \mathrm{mg} / \mathrm{kg}$ i.p.) (two-way repeated-measures ANOVA; genotype, $F_{(1,116)}=0.1, p=0.36$; time, $F_{(3,14)}=4.94$, $p<0.004$; genotype $\times$ time, $\left.F_{(3,14)}=0.26, p=0.62 ; n=5\right)$. These results suggest that TNF $\alpha$ only regulates the chronic but not the acute response to haloperidol. To ensure that the increased response to chronic haloperidol observed in the $T N F \alpha^{-1-}$ mice is not the result of any compensatory mechanisms resulting from the absence of TNF $\alpha$ during development, we treated WT mice with DN-TNF (30 mg/kg) 2 d before haloperidol injection and every other day thereafter at $15 \mathrm{mg} / \mathrm{kg}$ for 2 weeks. As with the $T N F \alpha^{-/-}$mice, WT mice treated with DNTNF had significantly higher VCM scores compared with control mice (Fig. $4 C ; n=8$ for control and DN-TNF). This suggests that soluble TNF $\alpha$ is regulating the development of the VCMs in a manner that limits the behavioral consequence of chronic haloperidol treatment. However, it is possible that, rather than chronically suppressing VCMs, TNF $\alpha$ signaling alters striatal plasticity in some way to limit the development of the motor symptoms in response to haloperidol. To address this possibility, we treated WT mice with haloperidol for 2 weeks, allowing the VCMs to develop normally. We measured the level of VCMs and then treated the animals with $30 \mathrm{mg} / \mathrm{kg} \mathrm{DN}-\mathrm{TNF}$, and reassessed VCMs $24 \mathrm{~h}$ later. Even this relatively acute blockade of TNF $\alpha$ signaling for previously established dysfunction resulted in a significant increase in VCMs (Fig. 4D). Together, these data suggest that ongoing TNF $\alpha$ signaling is suppressing the behavioral expression of the haloperidol-induced extrapyramidal symptoms.

To verify that TNF $\alpha$ does not regulate the surface expression of the dopamine D2 receptor, the target of haloperidol, we examined surface biotinylation of D2 receptors. The surface levels of D2 receptors from $\mathrm{TNF} \alpha$-treated striatal slices were insignificantly different compared with untreated slices from the same animals (Fig. 5A). Further, $T N F \alpha^{-/-}$mice have normal surface expression of D2 receptors (Fig. $5 B$ ). There was also no change in total D2 receptor expression in either case (TNF $\alpha$ treatment: $102.8 \pm 9.6 \%$ of control; $\mathrm{TNF}^{-/-}$mice: $88.2 \pm 21.5 \%$ of wildtype; $n=7$ per group). Overall, this suggests that the observed differences in VCMs are not the result of altered levels of D2 dopamine receptor. We further tested whether DARPP-32 phosphorylation is engaged during haloperidol-induced extrapyramidal symptoms. Phosphorylation of DARPP-32 is increased by acute haloperidol treatment (Håkansson et al., 2006), 
A

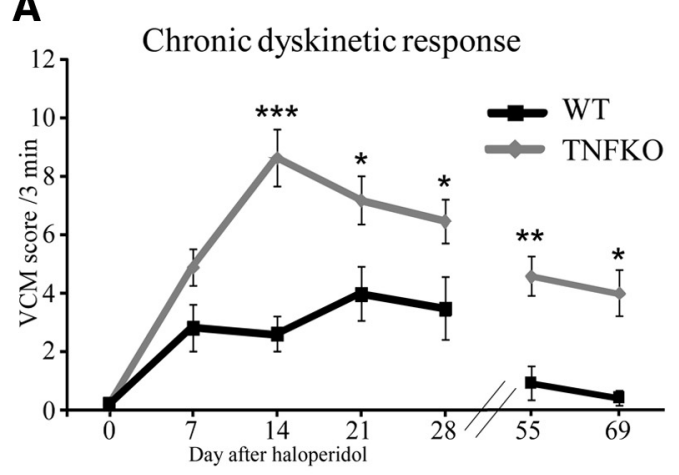

C
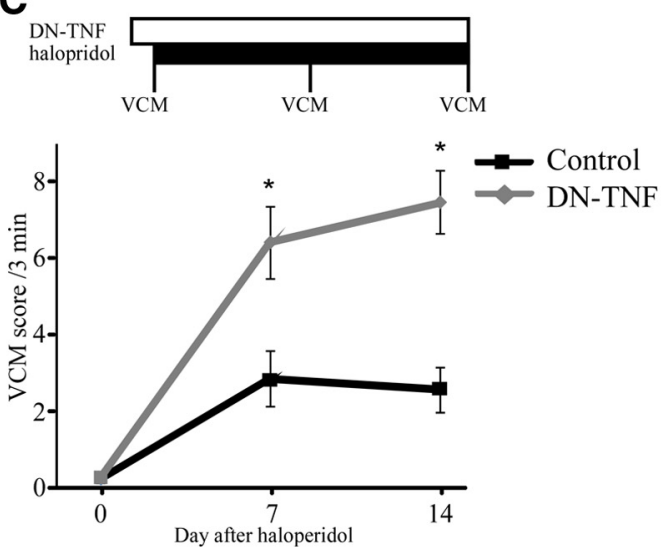

B

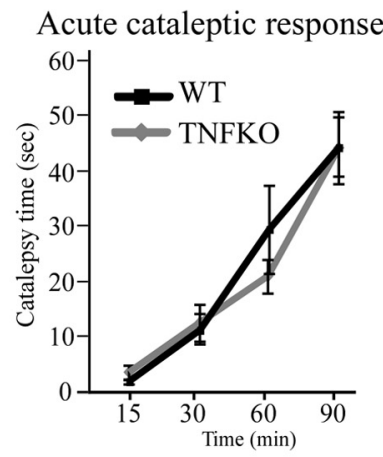

D
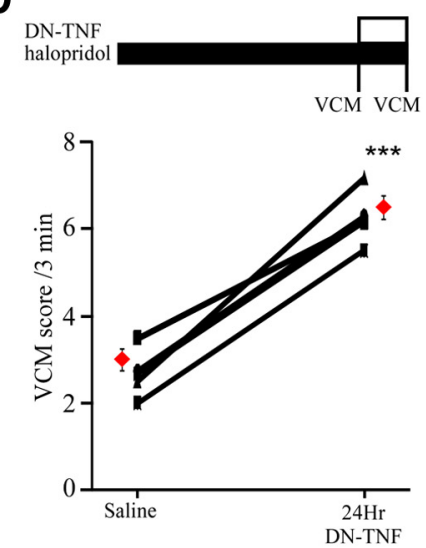

to NMDAR-mediated synaptic currents from MSNs in the dorsolateral striatum in WT and $T N F \alpha^{-1-}$ mice. Subchronic (14 d) haloperidol significantly increased the ratio of AMPA/NMDA current amplitudes in $T N F \alpha^{-1-}$ mice but only slightly but not significantly increased AMPA/ NMDA ratio in WT mice (Fig. $6 A, B$ ). In WT mice, the increase in AMPA/NMDA ratio was accompanied by an increase in rectification of the AMPA currents (Fig. $6 C)$, suggesting the preferential insertion of CP-AMPARs. To test whether these additional CP-AMPARs contribute to the extrapyramidal symptoms, we measured VCMs in WT mice treated with haloperidol for 2 weeks and injected $3 \mathrm{mg} / \mathrm{kg}$ of the CP-AMPAR antagonist IEM-1460 (i.p.), and reassessed the mice $20 \mathrm{~min}$ later. IEM treatment significantly reduced the number of VCMs by almost 30\% (Fig. $6 D$ ), whereas saline treatment led to a slight increase in VCMs, probably because of habituation to the assessment chamber (Fig. 6E). IEM-1460 alone, at this concentration, has been shown to have no adverse impact on motor performance on the rotarod (Kobylecki et al., 2010), although unilateral injection of IEM-1460 directly into the dorsolateral striatum can induce dystonia-like symptoms (Gittis et al., 2011). Therefore we evaluated whether the protocol we used can induced abnormal movement. Naive WT mice were injected intraperitoneally with $3 \mathrm{mg} / \mathrm{kg}$ IEM-1460 or saline, and monitored 20 min later for VCM development and overall locomotor activity. IEM did not induce VCMs (control, $0.16 \pm 0.16$; $n=4$ IEM, $0.33 \pm 0.13 ; n=4 ; p>0.46)$ or significantly alter locomotion (distance: control, $1670 \pm 64 \mathrm{~cm} ; n=4$; IEM, $1538 \pm 68 ; n=4 ; p>0.2$; average velocity: control, $5.6 \pm 0.2 \mathrm{~cm} / \mathrm{s} ; n=4$; IEM, $5.2 \pm 0.26 ; n=4 ; p>0.32$ ). Furthermore, mice injected with IEM displayed normal grooming behavior with no visible abnormal postures or movements.

but the effects of chronic treatment are unknown. We assessed the level of phospho-Thr34-DARPP-32 in animals treated for 2 weeks with haloperidol and compared it with animal that were treated with haloperidol for 2 weeks and then with DN-TNF for $24 \mathrm{~h}$. Mice treated with haloperidol had significantly less phosphoThr34-DARPP-32 compared with control mice, and this decrease was completely reversed with acute DN-TNF treatment (Fig. 5C). Thus, TNF $\alpha$ induces a downregulation of phospho-Thr34DARPP-32 in mice chronically treated with haloperidol and may alter corticostriatal synaptic strength in this model.

TNF $\alpha$ signaling reduces the synaptic and behavioral alteration induced by chronic haloperidol

To examine the physiological correlate of the behavior, we measured the effect of subchronic haloperidol treatment on AMPAR-

Overall, haloperidol leads to an increase in CP-AMPARs at MSN synapses, and these receptors contribute in part to the expression of VCMs. As the level of AMPAR insertion was significantly higher in haloperidol-treated $T N F \alpha^{-/-}$mice than in haloperidol-treated WT mice, we then examined whether exogenous application of TNF $\alpha$ would reduce the elevated AMPA/ NMDA ratio in $T N F \alpha^{-/-}$mice. Acute striatal slices from $\mathrm{TNF} \alpha^{-1-}$ mice chronically treated with haloperidol for $14 \mathrm{~d}$ were treated ex vivo with $100 \mathrm{ng} / \mathrm{ml}$ TNF $\alpha$ for $1-2 \mathrm{~h}$. This treatment significantly reduced the ratio of AMPA/NMDA current amplitudes compared with untreated TNF $\alpha^{-/-}$(Fig. $6 F$ ), to levels indistinguishable from WT mice. These data suggest that TNF $\alpha$ is part of an adaptive response to the change in circuit function due to subchronic blockade of D2 receptors, and that by reducing the 

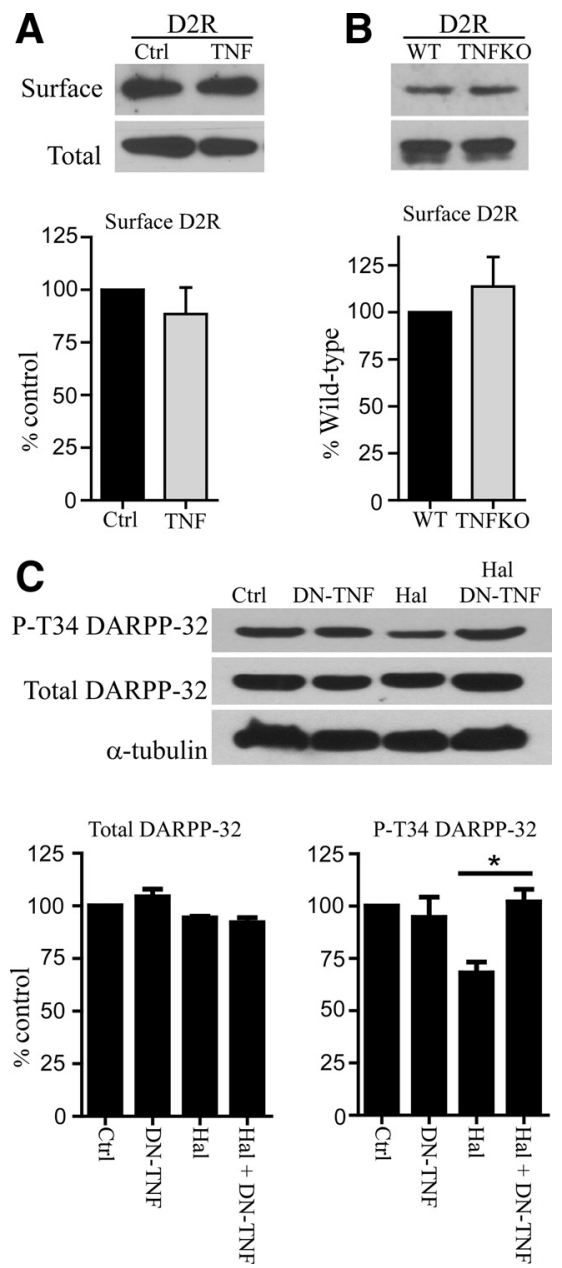

Figure 5. TNF $\alpha$ treatment reduces DARPP-32 phosphorylation in the striatum after haloperidol treatment. A, Striatal slices were treated with $\operatorname{TNF} \alpha 100 \mathrm{ng} / \mathrm{ml}$ for $1 \mathrm{~h}$ and analyzed by surface biotinylation for dopamine D2 receptors ( $n=7$ mice). No significant difference was observed $(p=0.35)$. $\boldsymbol{B}$, Striatal slices from TNF $\alpha^{-l-}$ mice were compared with WT mice for the surface expression of $\mathrm{D} 2$ receptors ( $n=7$ mice per group). No significant difference was observed ( $p=0.68$ ). C, Mice were treated with haloperidol for 2 weeks and analyzed for total DARPP-32 and phospho-DARPP-32 T34 in the striatum. Two weeks of haloperidol significantly reduced striatal Thr34 phosphorylation compared with untreated control striatum; however, $24 \mathrm{~h}$ treatment with DN-TNF in haloperidol-treated mice restored Thr34 phosphorylation to control levels ( $n=4$ mice per group). Data are mean \pm SEM. $\boldsymbol{A}, \boldsymbol{B},{ }^{*} p<0.05$, versus control (Mann-Whitney test). C, ${ }^{*} p<0.05$, versus control (one-way ANOVA with a post hoc KruskalWallis test).

synaptic changes in the striatum, TNF $\alpha$ may reduce the expression of VCMs.

To test this idea, we examined whether increasing the levels of TNF $\alpha$ could reduce VCMs induced by haloperidol. Given that injection of $\mathrm{TNF} \alpha$ systemically or locally can induce sickness behavior as well as increased levels of other proinflammatory cytokines (Cao et al., 1998; Chida and Iwakura, 2007), we repeated the VCM behavioral experiment using DN-TNF, except that in one group we administered DN-TNF for only 1 week, which allows the gradual return of soluble TNF $\alpha$ signaling during the second week. Although both DN-TNF-treated groups had higher VCM scores after 1 week compared with control, stopping the treatment of DN-TNF reduced the VCM scores to control levels at week 2 (Fig. $6 G$ ). These results indicate that restoring physiological levels of TNF $\alpha$ can return the expression of VCMs to normal levels. Together, these data suggest that $\mathrm{TNF} \alpha$ is me-
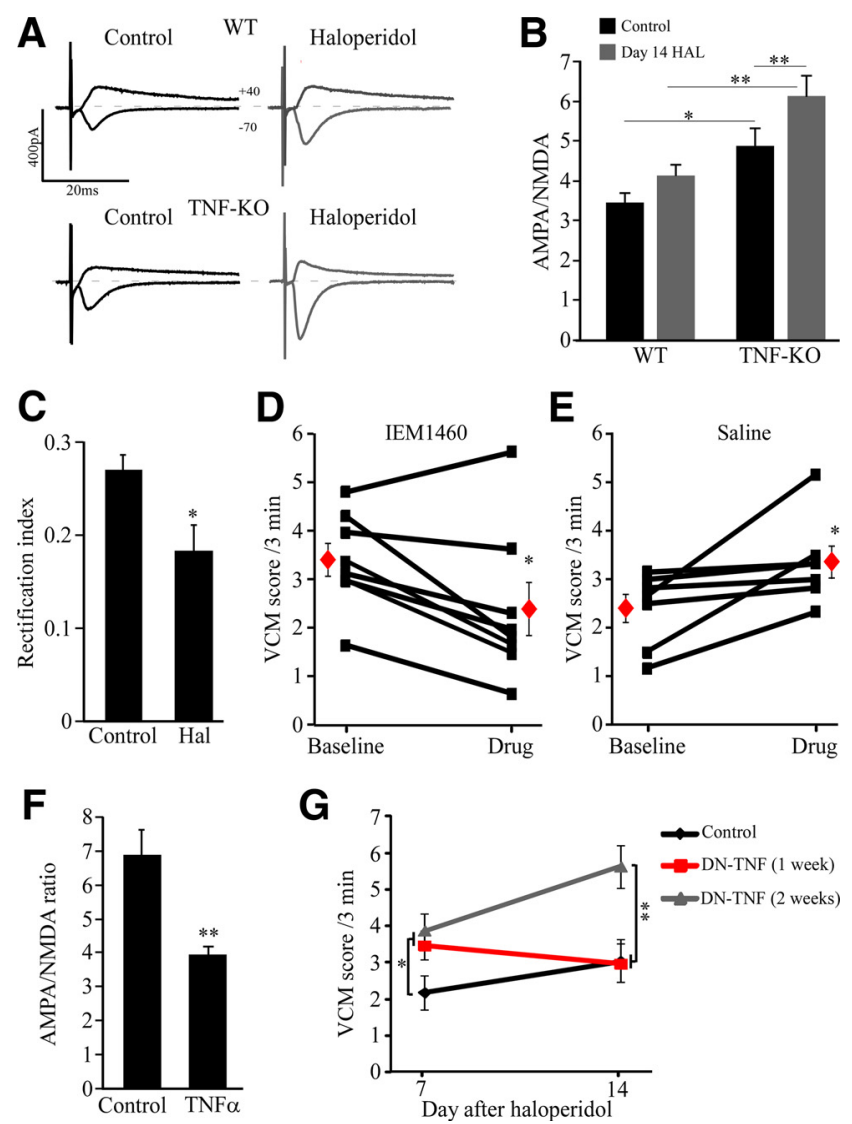

Figure 6. TNF $\alpha$ signaling limits the abnormal synaptic and behavioral alterations induced by chronic haloperidol. $\boldsymbol{A}$, Representative traces from striatal medium spiny neurons held at $-70 \mathrm{mV}$ (bottom) and $+40 \mathrm{mV}$ (top) $14 \mathrm{~d}$ after haloperidol injection in WT mice or TNF $\alpha^{-1-}$ mice. $B$, Group data showing that haloperidol significantly increased the ratio of AMPA to NMDA current amplitudes in TNF $\alpha^{-/-}$compared with naive mice, but this effect was not significant in WT ( $n=15$ or 16 per group). A one-way ANOVA indicates a significant difference between the groups $\left(F_{(3,61)}=9.52, p<0.0001\right)$. C, Group data demonstrating that synapses from slices obtained from mice after $14 \mathrm{~d}$ of haloperidol have a significantly higher rectification. The $\mathrm{Rl}$ is expressed as EPSC amplitude $+40 \mathrm{mv} /$ EPSC amplitude $-70 \mathrm{mv}$, with a larger ratio indicating less rectification ( $n=9$ haloperidol, 13 control; $p=0.015$ ). $\boldsymbol{D}$, Effects of acute blockade of (PAMPAR on VCMs at day 14 after haloperidol. WT mice were injected with haloperidol. After $14 \mathrm{~d}$ VCMs were counted and mice were injected with IEM-1460 (3 mg/kg) or saline. At 20 min later, VCMs were counted again. IEM-1460 significantly reduced VCM levels (paired $t$ test; $p=0.02$; $n=8)$. $\boldsymbol{E}$, In contrast, mice treated with saline had significantly higher levels of VCMs after injection (paired $t$ test; $p=0.04 ; n=7$ ). $\boldsymbol{F}$, Striatal slices from $T N F \alpha^{-/-}$mice chronically treated with haloperidol for $14 \mathrm{~d}$ were treated ex vivo with $100 \mathrm{ng} / \mathrm{ml}$ TNF $\alpha$ for $1-2 \mathrm{~h}$. TNF $\alpha$ treatment significantly reduced the AMPA/NMDA ratio $(n=11-13 ; p=0.0017) . \mathbf{G}$, Effects of chronic haloperidol on VCMs after stopping treatment with dominant-negative TNF $\alpha$. WT mice were administered with DN-TNF either for 2 weeks or just for the first week and compared with untreated mice. Stopping the treatment of DN-TNF reduced the level of VCMs to that of control mice ( $n=9-11$ mice per group). Two-way repeated-measures ANOVA: treatment, $F_{(2,26)}=$ $0.05, p=0.0048$; days, $F_{(1,26)}=0.17, p=0.042$; treatment $\times$ days, $F_{(2,26)}=0.28, p=$ 0.038. Data are mean \pm SEM. ${ }^{*} p<0.05 .{ }^{* *} p<0.01$.

diating an adaptive response in the striatum to the chronic presence of haloperidol.

\section{Discussion}

Our data demonstrate that TNF $\alpha$ is a regulator of AMPAR content at the corticostriatal pathway, with some selectivity for the removal of CP-AMPAR. Furthermore, TNF $\alpha$ has an adaptive role in restricting both the physiological and behavioral effects of chronic haloperidol treatment. Our findings suggest that TNF $\alpha$ is a major regulator of striatal function and loss of TNF $\alpha$ signaling increases vulnerability to corticostriatal dysfunction. 
TNF $\alpha$ treatment was previously shown to induce the rapid exocytosis of CP-AMPARs in excitatory neurons, whereas blocking TNF $\alpha$ reduced AMPAR surface expression in cortical (He et al., 2012) and hippocampal pyramidal cells (Ogoshi et al., 2005; Stellwagen et al., 2005) and in motor neurons (Ferguson et al., 2008). In contrast, TNF $\alpha$ signaling reduces AMPAR content in MSNs through the preferential removal of CP-AMPARs. One possible explanation for this discrepancy is a developmental regulation of $\mathrm{TNF} \alpha$-mediated trafficking, with this work being done in relatively mature tissue (8- to 10 -week-old mice) compared with earlier experiments. However, treatment of TNF $\alpha$ in acute hippocampal slices from adult mice resulted in an increase of AMPA/NMDA ratio in the CA1 pyramidal neurons. Moreover, neurons in the adult amygdala respond to acute TNF $\alpha$ treatment by strengthening glutamatergic synapses (Chen et al., 2013). More likely, the difference is the result of MSNs being inhibitory cells. Reducing excitatory drive on inhibitory neurons will lead to an overall decrease in inhibition; thus, $\operatorname{TNF} \alpha$ would have a similar effect on circuit properties in both systems. Our results are supported by the observation that blocking activity in hippocampal cultures, which leads to TNF $\alpha$-dependent increase of AMPARs on excitatory pyramidal neurons, reduces AMPARs on a subset of parvalbumin-expressing interneurons (Chang et al., 2010). Another possibility is that MSNs express high levels of DARPP-32 (Walaas et al., 1983) and that, in these cells, TNF $\alpha$ signaling through the DARPP-32 pathway inverts the AMPAR trafficking through activation of PP1. $\mathrm{TNF} \alpha$ is known to activate PP1 in hippocampal pyramidal neurons, but this activity is localized to inhibitory synapses where it is required for the $\mathrm{TNF} \alpha$-induced endocyosis of GABA-A receptors (Pribiag and Stellwagen, 2013). Whereas the regulation of various $\mathrm{PP} 1$ binding proteins can be similar, the targeting can be different. Thus, MSNs, which express DARPP-32 unlike hippocampal cells, may target PP1 to excitatory synapses and result in the endocytosis of AMPARs.

Striatal levels of TNF $\alpha$ increase during many motor disorders and inflammatory conditions, which are also accompanied with alterations in the corticostriatal pathway. As TNF $\alpha$ is involved in homeostatic synaptic plasticity, we hypothesized that the increase of TNF $\alpha$ is part of a compensatory response to the abnormal corticostriatal plasticity. To test this idea, we selected a simple animal model of abnormal striatal function involving elevated TNF $\alpha$ levels in the striatum (Bishnoi et al., 2008) as well as alterations in AMPARs and enhanced excitatory transmission in the corticostriatal pathway (Schmitt et al., 2003; Centonze et al., 2004). Subchronic haloperidol, as generally used here, is more likely a model of Parkinsonism and drug-induced extrapyramidal symptoms, whereas chronic haloperidol transitions into a model of tardive dyskinesia (Egan et al., 1996). However, based on the elevated VCMs across a 10 week experiment, TNF $\alpha$ signaling likely diminishes both of these striatal motor dysfunctions.

Dopamine is well documented as a regulator of corticostriatal synapses (Chase and Oh, 2000; Chase et al., 2003; Calabresi et al., 2010), and dysregulation of these synapses is thought to underlie extrapyramidal syndromes (Chase, 2004; Calabresi et al., 2010; Sgambato-Faure and Cenci, 2012). Inhibition of D2 receptors or activation of D1 receptors leads to PKA-dependent phosphorylation of both DARPP-32 (resulting in inhibition of PP1) and S845 on GluA1. This will increase the surface expression of GluA1-containing AMPARs (Mangiavacchi and Wolf, 2004).
Acute haloperidol treatment has been observed to transiently increase both DARPP-32 and GluA1-S845 phosphorylation in vivo (Håkansson et al., 2006). However, with chronic haloperidol, there is a downregulation of phospho-Thr34-DARPP-32 because of an increase in TNF $\alpha$ signaling. Correspondingly, acute haloperidol was shown to increase phosphorylation of ribosomal protein S6, which required Thr34 phosphorylation of DARPP32; however, this effect is lost when haloperidol is administered chronically (Valjent et al., 2011). Similar changes in DARPP32 occur during other striatal dysfunctions, suggesting a broader role for TNF $\alpha$ in regulating striatal synapses. As with haloperidol, acute injection of cocaine is also associated with increase phospho-Thr34-DARPP-32 in the striatum (Nishi et al., 2000), whereas chronic treatment with cocaine is associated with a decrease in phospho-Thr34-DARPP-32 (Bibb et al., 2001). A related extrapyramidal syndrome, L-DOPA induced dyskinesia, which is primarily mediated through D1 activation, is also associated with strengthening of corticostriatal synapses (Jenner, 2008; Calabresi et al., 2010; Cenci and Konradi, 2010). The added AMPARs may be $\mathrm{Ca}^{2+}$-permeable, as we observe an increase in AMPAR rectification, and the VCMs can be partially blocked by IEM-1460. This regimen was similarly effective against L-DOPAinduced dyskinesia, without generally affecting motor function (Kobylecki et al., 2010); a partial blockade of all AMPARs also reduces L-DOPA-induced dyskinesia (Konitsiotis et al., 2000). Furthermore, treatment with L-DOPA did not reduce inwardrectifying AMPAR currents induced by 6-OHDA-lesion. However pramipexole, which was shown to have antiparkinsonian effects and be associated with reduced dyskinesia, could reverse the alteration of glutamatergic transmission as well as restore rectification values to control levels (Bagetta et al., 2012). Controlling the CP-AMPAR content of synapses may therefore be critical to treating striatal motor dysfunctions.

To fully understand the effect of TNF $\alpha$ on striatal function will necessitate examining the effect of TNF $\alpha$ on the direct and indirect pathway MSNs. Although we do not directly address this issue here, it seems likely that TNF $\alpha$ acts on both types of MSNs. All MSNs appeared to have reduced AMPA/NMDA ratios in response to TNF $\alpha$ (Fig. 1B), and the reduction in AMPAR surface expression is too large for TNF $\alpha$ to be acting at a subset of MSNs. However, TNF $\alpha$ may have a stronger effect on recently altered MSN synapses. Chronic haloperidol increases AMPAR rectification, suggesting the insertion of new CP-AMPARs. As TNF $\alpha$ preferentially acts on these receptors, TNF $\alpha$ will more strongly affect newly altered synapses and thereby help restore circuit function.

Our data support a model of enhanced corticostriatal transmission in the development of drug induced extrapyramidal symptoms and the increase in synaptic strength correlates with the degree of motor dysfunction. Blocking TNF $\alpha$ signaling increases both the corticostriatal synaptic strength and the level of VCMs. TNF $\alpha$ appears to act through a similar pathway as dopamine in regulating these synapses, by dephosphorylating DARPP-32 and GluA1 and thereby decreasing the surface expression of AMPARs. Critically, even an acute blockade of TNF $\alpha$ can worsen symptoms, and restoring TNF $\alpha$ signaling will reverse this effect. This suggests that TNF $\alpha$ is acting adaptively to reduce the aberrant corticostriatal synaptic strength and suppress the magnitude of the VCMs. Similarly, in humans, polymorphism in the $\mathrm{TNF} \alpha$ promoter that results in increased TNF $\alpha$ production is associated with less severe symptoms of tardive dyskinesia (Wang et al., 2012), a consequence of chronic haloperidol administration. However, we cannot rule out that, with progression of stri- 
atal disorders, TNF $\alpha$ levels could increase to levels that can lead to $\mathrm{TNF} \alpha$-induced cell death. It is important to note that the incidence of tardive dyskinesia is significantly lower with atypical antipsychotic drugs, such as clozapine (Margolese et al., 2005). One possible reason for the lower incidence is that chronic haloperidol increases AMPAR binding in striatum, nucleus accumbens, cingulated cortex, and insular cortex, whereas clozapine shows increased AMPAR binding only in the anterior cingulated cortex (McCoy et al., 1996; Schmitt et al., 2003). Alternatively, clozapine may cause smaller changes within the striatum that can be fully compensated by TNF $\alpha$ signaling, whereas haloperidol causes larger increases in synaptic strength that can only be partially compensated by TNF $\alpha$.

In the CNS, the effects of TNF $\alpha$ are complex, with evidence for both injury-promoting and neuroprotective effects (Fontaine et al., 2002; McCoy and Tansey, 2008; Chertoff et al., 2011). Moreover, TNF $\alpha$ levels are elevated in patients and animal model of movement disorder, such as HD (Sapp et al., 2001), PD (Mogi et al., 1999), and other basal ganglia disorders, such as OCD (Konuk et al., 2007), schizophrenia (Miller et al., 2011), and addiction (Yamada and Nabeshima, 2004). Although it has been suggested that TNF $\alpha$ is detrimental in these pathologies, we propose that, at early stages of striatal dysfunction, TNF $\alpha$ has an adaptive role by specifically inducing endocytosis of CP-AMPARs and reducing synaptic strength of the corticostratal pathway. Thus, blocking TNF $\alpha$ signaling in the treatment of movement disorders may complicate the therapies and exacerbate the motor symptoms in early phases of the disease. However, constant activation of this compensatory system may lead to persistent high levels of TNF $\alpha$ that could also be detrimental to the system. Overall, our data establish that TNF $\alpha$ is a key element in maintaining the normal function of this circuit and that the robustness of striatal compensatory systems may set the symptom susceptibility in these maladies.

\section{References}

Bagetta V, Sgobio C, Pendolino V, Del Papa G, Tozzi A, Ghiglieri V, Giampà C, Zianni E, Gardoni F, Calabresi P, Picconi B (2012) Rebalance of striatal NMDA/AMPA receptor ratio underlies the reduced emergence of dyskinesia during D2-like dopamine agonist treatment in experimental Parkinson's disease. J Neurosci 32:17921-17931. CrossRef Medline

Beattie EC, Stellwagen D, Morishita W, Bresnahan JC, Ha BK, Von Zastrow M, Beattie MS, Malenka RC (2002) Control of synaptic strength by glial TNFalpha. Science 295:2282-2285. CrossRef Medline

Bibb JA, Chen J, Taylor JR, Svenningsson P, Nishi A, Snyder GL, Yan Z, Sagawa ZK, Ouimet CC, Nairn AC, Nestler EJ, Greengard P (2001) Effects of chronic exposure to cocaine are regulated by the neuronal protein Cdk5. Nature 410:376-380. CrossRef Medline

Bishnoi M, Chopra K, Kulkarni SK (2008) Differential striatal levels of TNFalpha, NFkappaB p65 subunit and dopamine with chronic typical and atypical neuroleptic treatment: role in orofacial dyskinesia. Prog Neuropsychopharmacol Biol Psychiatry 32:1473-1478. CrossRef Medline

Bowie D, Mayer ML (1995) Inward rectification of both AMPA and kainate subtype glutamate receptors generated by polyamine-mediated ion channel block. Neuron 15:453-462. CrossRef Medline

Breakefield XO, Blood AJ, Li Y, Hallett M, Hanson PI, Standaert DG (2008) The pathophysiological basis of dystonias. Nat Rev Neurosci 9:222-234. CrossRef Medline

Calabresi P, Di Filippo M, Ghiglieri V, Tambasco N, Picconi B (2010) Levodopa-induced dyskinesias in patients with Parkinson's disease: filling the bench-to-bedside gap. Lancet Neurol 9:1106-1117. CrossRef Medline

Cao C, Matsumura K, Yamagata K, Watanabe Y (1998) Cyclooxygenase-2 is induced in brain blood vessels during fever evoked by peripheral or central administration of tumor necrosis factor. Brain Res Mol Brain Res 56:45-56. CrossRef Medline

Carter AG, Sabatini BL (2004) State-dependent calcium signaling in den- dritic spines of striatal medium spiny neurons. Neuron 44:483-493. CrossRef Medline

Cenci MA, Konradi C (2010) Maladaptive striatal plasticity in L-DOPAinduced dyskinesia. Prog Brain Res 183:209-233. CrossRef Medline

Centonze D, Usiello A, Costa C, Picconi B, Erbs E, Bernardi G, Borrelli E, Calabresi P (2004) Chronic haloperidol promotes corticostriatal longterm potentiation by targeting dopamine D2L receptors. J Neurosci 24: 8214-8222. CrossRef Medline

Chang MC, Park JM, Pelkey KA, Grabenstatter HL, Xu D, Linden DJ, Sutula TP, McBain CJ, Worley PF (2010) Narp regulates homeostatic scaling of excitatory synapses on parvalbumin-expressing interneurons. Nat Neurosci 13:1090-1097. CrossRef Medline

Chase TN (2004) Striatal plasticity and extrapyramidal motor dysfunction. Parkinsonism Relat Disord 10:305-313. CrossRef Medline

Chase TN, Oh JD (2000) Striatal dopamine- and glutamate-mediated dysregulation in experimental parkinsonism. Trends Neurosci 23:S86-S91. CrossRef Medline

Chase TN, Bibbiani F, Oh JD (2003) Striatal glutamatergic mechanisms and extrapyramidal movement disorders. Neurotox Res 5:139-146. CrossRef Medline

Chen J, Song Y, Yang J, Zhang Y, Zhao P, Zhu XJ, Su HC (2013) The contribution of TNF- $\alpha$ in the amygdala to anxiety in mice with persistent inflammatory pain. Neurosci Lett 541:275-280. CrossRef Medline

Chertoff M, Di Paolo N, Schoeneberg A, Depino A, Ferrari C, Wurst W, Pfizenmaier K, Eisel U, Pitossi F (2011) Neuroprotective and neurodegenerative effects of the chronic expression of tumor necrosis factor alpha in the nigrostriatal dopaminergic circuit of adult mice. Exp Neurol 227: 237-251. CrossRef Medline

Chida D, Iwakura Y (2007) Peripheral TNFalpha, but not peripheral IL-1, requires endogenous IL-1 or TNFalpha induction in the brain for the febrile response. Biochem Biophys Res Commun 364:765-770. CrossRef Medline

Ding J, Peterson JD, Surmeier DJ (2008) Corticostriatal and thalamostriatal synapses have distinctive properties. J Neurosci 28:6483-6492. CrossRef Medline

Dobrunz LE, Stevens CF (1997) Heterogeneity of release probability, facilitation, and depletion at central synapses. Neuron 18:995-1008. CrossRef Medline

Egan MF, Hurd Y, Ferguson J, Bachus SE, Hamid EH, Hyde TM (1996) Pharmacological and neurochemical differences between acute and tardive vacuous chewing movements induced by haloperidol. Psychopharmacology 127:337-345. CrossRef Medline

Ethier I, Kagechika H, Shudo K, Rouillard C, Lévesque D (2004) Docosahexaenoic acid reduces haloperidol-induced dyskinesias in mice: involvement of Nur77 and retinoid receptors. Biol Psychiatry 56:522-526. CrossRef Medline

Ferguson AR, Christensen RN, Gensel JC, Miller BA, Sun F, Beattie EC, Bresnahan JC, Beattie MS (2008) Cell death after spinal cord injury is exacerbated by rapid TNF alpha-induced trafficking of GluR2-lacking AMPARs to the plasma membrane. J Neurosci 28:11391-11400. CrossRef Medline

Fontaine V, Mohand-Said S, Hanoteau N, Fuchs C, Pfizenmaier K, Eisel U (2002) Neurodegenerative and neuroprotective effects of tumor necrosis factor (TNF) in retinal ischemia: opposite roles of TNF receptor 1 and TNF receptor 2. J Neurosci 22:RC216. Medline

Gittis AH, Leventhal DK, Fensterheim BA, Pettibone JR, Berke JD, Kreitzer AC (2011) Selective inhibition of striatal fast-spiking interneurons causes dyskinesias. J Neurosci 31:15727-15731. CrossRef Medline

Håkansson K, Galdi S, Hendrick J, Snyder G, Greengard P, Fisone G (2006) Regulation of phosphorylation of the GluR1 AMPA receptor by dopamine D2 receptors. J Neurochem 96:482-488. CrossRef Medline

He P, Liu Q, Wu J, Shen Y (2012) Genetic deletion of TNF receptor suppresses excitatory synaptic transmission via reducing AMPA receptor synaptic localization in cortical neurons. FASEB J 26:334-345. CrossRef Medline

Jenner P (2008) Molecular mechanisms of L-DOPA-induced dyskinesia. Nat Rev Neurosci 9:665-677. CrossRef Medline

Jones EV, Bernardinelli Y, Tse YC, Chierzi S, Wong TP, Murai KK (2011) Astrocytes control glutamate receptor levels at developing synapses through SPARC-beta-integrin interactions. J Neurosci 31:4154-4165. CrossRef Medline

Kamboj SK, Swanson GT, Cull-Candy SG (1995) Intracellular spermine 
confers rectification on rat calcium-permeable AMPA and kainate receptors. J Physiol 486:297-303. Medline

Kaneko M, Stellwagen D, Malenka RC, Stryker MP (2008) Tumor necrosis factor-alpha mediates one component of competitive, experiencedependent plasticity in developing visual cortex. Neuron 58:673-680. CrossRef Medline

Khandelwal PJ, Herman AM, Moussa CE (2011) Inflammation in the early stages of neurodegenerative pathology. J Neuroimmunol 238:1-11. CrossRef Medline

Kobylecki C, Cenci MA, Crossman AR, Ravenscroft P (2010) Calciumpermeable AMPA receptors are involved in the induction and expression of 1-DOPA-induced dyskinesia in Parkinson's disease. J Neurochem 114: 499-511. CrossRef Medline

Konitsiotis S, Blanchet PJ, Verhagen L, Lamers E, Chase TN (2000) AMPA receptor blockade improves levodopa-induced dyskinesia in MPTP monkeys. Neurology 54:1589-1595. CrossRef Medline

Konuk N, Tekin IO, Ozturk U, Atik L, Atasoy N, Bektas S, Erdogan A (2007) Plasma levels of tumor necrosis factor-alpha and interleukin-6 in obsessive compulsive disorder. Mediators Inflamm 2007:65704. CrossRef Medline

Kreitzer AC, Malenka RC (2008) Striatal plasticity and basal ganglia circuit function. Neuron 60:543-554. CrossRef Medline

Mangiavacchi S, Wolf ME (2004) D1 dopamine receptor stimulation increases the rate of AMPA receptor insertion onto the surface of cultured nucleus accumbens neurons through a pathway dependent on protein kinase A. J Neurochem 88:1261-1271. CrossRef Medline

Margolese HC, Chouinard G, Kolivakis TT, Beauclair L, Miller R, Annable L (2005) Tardive dyskinesia in the era of typical and atypical antipsychotics: 2. Incidence and management strategies in patients with schizophrenia. Can J Psychiatry 50:703-714. Medline

McCoy L, Cox C, Richfield EK (1996) Chronic treatment with typical and atypical antipsychotics increases the AMPA-preferring form of AMPA receptor in rat brain. Eur J Pharmacol 318:41-45. CrossRef Medline

McCoy MK, Tansey MG (2008) TNF signaling inhibition in the CNS: implications for normal brain function and neurodegenerative disease. J Neuroinflammation 5:45. CrossRef Medline

Miller BJ, Buckley P, Seabolt W, Mellor A, Kirkpatrick B (2011) Metaanalysis of cytokine alterations in schizophrenia: clinical status and antipsychotic effects. Biol Psychiatry 70:663-671. CrossRef Medline

Milnerwood AJ, Raymond LA (2007) Corticostriatal synaptic function in mouse models of Huntington's disease: early effects of huntingtin repeat length and protein load. J Physiol 585:817-831. CrossRef Medline

Mogi M, Togari A, Tanaka K, Ogawa N, Ichinose H, Nagatsu T (1999) Increase in level of tumor necrosis factor (TNF)-alpha in 6-hydroxydopaminelesioned striatum in rats without influence of systemic L-DOPA on the TNFalpha induction. Neurosci Lett 268:101-104. CrossRef Medline

Murer MG, Tseng KY, Kasanetz F, Belluscio M, Riquelme LA (2002) Brain oscillations, medium spiny neurons, and dopamine. Cell Mol Neurobiol 22:611-632. CrossRef Medline

Nishi A, Bibb JA, Snyder GL, Higashi H, Nairn AC, Greengard P (2000) Amplification of dopaminergic signaling by a positive feedback loop. Proc Natl Acad Sci U S A 97:12840-12845. CrossRef Medline

Ogoshi F, Yin HZ, Kuppumbatti Y, Song B, Amindari S, Weiss JH (2005) Tumor necrosis-factor-alpha (TNF-alpha) induces rapid insertion of $\mathrm{Ca}^{2+}$-permeable alpha-amino-3-hydroxyl-5-methyl-4-isoxazolepropionate (AMPA)/kainate $(\mathrm{Ca}-\mathrm{A} / \mathrm{K})$ channels in a subset of hippocampal pyramidal neurons. Exp Neurol 193:384-393. CrossRef Medline

Pribiag H, Stellwagen D (2013) TNF-alpha downregulates inhibitory neurotransmission through protein phosphatase 1-dependent trafficking of GABA(A) receptors. J Neurosci 33:15879-15893. CrossRef Medline
Ranson A, Cheetham CE, Fox K, Sengpiel F (2012) Homeostatic plasticity mechanisms are required for juvenile, but not adult, ocular dominance plasticity. Proc Natl Acad Sci U S A 109:1311-1316. CrossRef Medline

Sanberg PR (1980) Haloperidol-induced catalepsy is mediated by postsynaptic dopamine receptors. Nature 284:472-473. CrossRef Medline

Sanberg PR, Bunsey MD, Giordano M, Norman AB (1988) The catalepsy test: its ups and downs. Behav Neurosci 102:748-759. CrossRef Medline

Sapp E, Kegel KB, Aronin N, Hashikawa T, Uchiyama Y, Tohyama K, Bhide PG, Vonsattel JP, DiFiglia M (2001) Early and progressive accumulation of reactive microglia in the Huntington disease brain. J Neuropathol Exp Neurol 60:161-172. Medline

Schmitt A, May B, Müller B, Jatzko A, Petroianu G, Braus DF, Henn FA (2003) Effects of chronic haloperidol and clozapine treatment on AMPA and kainate receptor binding in rat brain. Pharmacopsychiatry 36:292296. CrossRef Medline

Sgambato-Faure V, Cenci MA (2012) Glutamatergic mechanisms in the dyskinesias induced by pharmacological dopamine replacement and deep brain stimulation for the treatment of Parkinson's disease. Prog Neurobiol 96:69-86. CrossRef Medline

Smith JA, Das A, Ray SK, Banik NL (2012) Role of pro-inflammatory cytokines released from microglia in neurodegenerative diseases. Brain Res Bull 87:10-20. CrossRef Medline

Steed PM, Tansey MG, Zalevsky J, Zhukovsky EA, Desjarlais JR, Szymkowski DE, Abbott C, Carmichael D, Chan C, Cherry L, Cheung P, Chirino AJ, Chung HH, Doberstein SK, Eivazi A, Filikov AV, Gao SX, Hubert RS, Hwang M, Hyun L, et al. (2003) Inactivation of TNF signaling by rationally designed dominant-negative TNF variants. Science 301:1895-1898. CrossRef Medline

Stellwagen D, Malenka RC (2006) Synaptic scaling mediated by glial TNFalpha. Nature 440:1054-1059. CrossRef Medline

Stellwagen D, Beattie EC, Seo JY, Malenka RC (2005) Differential regulation of AMPA receptor and GABA receptor trafficking by tumor necrosis factor-alpha. J Neurosci 25:3219-3228. CrossRef Medline

Tang KC, Lovinger DM (2000) Role of pertussis toxin-sensitive G-proteins in synaptic transmission and plasticity at corticostriatal synapses. J Neurophysiol 83:60-69. Medline

Valjent E, Bertran-Gonzalez J, Bowling H, Lopez S, Santini E, Matamales M, Bonito-Oliva A, Hervé D, Hoeffer C, Klann E, Girault JA, Fisone G (2011) Haloperidol regulates the state of phosphorylation of ribosomal protein S6 via activation of PKA and phosphorylation of DARPP-32. Neuropsychopharmacology 36:2561-2570. CrossRef Medline

Walaas SI, Aswad DW, Greengard P (1983) A dopamine- and cyclic AMPregulated phosphoprotein enriched in dopamine-innervated brain regions. Nature 301:69-71. CrossRef Medline

Wang F, Fan H, Sun H, Yang F, Luo Y, Liu H, Kosten TR, Lu L, Zhang XY (2012) Association between TNF-alpha promoter -308A/G polymorphism and tardive dyskinesiain Chinese Han patients with schizophrenia. Prog Neuropsychopharmacol Biol Psychiatry 37:106-110. CrossRef Medline

Watson JB, Hatami A, David H, Masliah E, Roberts K, Evans CE, Levine MS (2009) Alterations in corticostriatal synaptic plasticity in mice overexpressing human alpha-synuclein. Neuroscience 159:501-513. CrossRef Medline

Yamada K, Nabeshima T (2004) Pro- and anti-addictive neurotrophic factors and cytokines in psychostimulant addiction: mini review. Ann N Y Acad Sci 1025:198-204. CrossRef Medline

Yan Z, Hsieh-Wilson L, Feng J, Tomizawa K, Allen PB, Fienberg AA, Nairn AC, Greengard P (1999) Protein phosphatase 1 modulation of neostriatal AMPA channels: regulation by DARPP-32 and spinophilin. Nat Neurosci 2:13-17. CrossRef Medline 